\title{
Introduction to Copyright and Collective Management in Competition Law
}

\author{
JORG SLADIČ
}

\begin{abstract}
Copyright is an absolute intellectual property right. Historically it is of territorial nature. One of the central issues of copyright is the remuneration of authors. A copyright confers to its holder a legal monopoly comprising certain economic rights that are granted for pecuniary consideration. The economically most efficient way of management of copyright's pecuniary consideration is the collective management. However, collective management covers due to territorial nature of copyright only territory of a certain state. In competition law that might be considered as a monopoly by collecting societies limited to borders of states, in other words there are issues of a possible abuse of a dominant position.
\end{abstract}

Keywords: $\bullet$ copyright $\bullet$ common law $\bullet$ droit d'auteur $\bullet$ civil law $\bullet$ collective management $\bullet$ intellectual property rights $\bullet$ dominant position $\bullet$ abuse of a dominant position $\bullet$ principle of solidarity $\bullet$ copyright related market $\bullet$ search market

CORRESPONDENCE ADDRESS: Dr. Jorg Sladič, assistant professor, law firm Sladič - Zemljak, Kersnikova ul. 7, SI-1000 Ljubljana, Slovenia, e-mail: advokat.sladic@sedmica.net

ISSN 1855-7147 Print / 1855-7155 On-line C 2013 LeXonomica (Maribor)

UDC: $347.78: 339.137$

JEL: K21, L40, O34

Available on-line at http://www.lexonomica.com 


\title{
Uvod $\mathrm{v}$ avtorsko pravico in kolektivno upravljanje $v$ konkurenčnem pravu
}

\author{
JORG SLADIČ
}

\section{Povzetek}

Avtorska pravica je absolutna pravica intelektualne lastnine. Zgodovinsko je teritorialne narave. Eno od bistvenih vprašanj avtorske pravice je plačilo avtorjev. Avtorska pravica imetnikom podeli zakonit monopol nad nekaterimi materialnimi avtorskimi pravicami, ki se odstopijo odplačno. Ekonomsko najbolj učinkovitejši način upravljanja denarnega plačila za avtorske pravice je kolektivno upravljanje. Zaradi teritorialne narave avtorske pravice to zajema zgolj ozemlje določene države. To pa se v konkurenčnem pravu lahko obravnava kot monopolni oz. prevladujoč položaj organizacij za kolektivno upravljanje, s tem pa tudi vprašanje možne zlorabe takšnega položaja.

Ključne besede: - copyright - common law - avtorska pravica • kontinentalno pravo $\bullet$ kolektivno upravljanja $\bullet$ pravice intelektualne lastnine $\bullet$ prevladujoč položaj • zloraba prevladujočega položaja $\bullet$ načelo solidarnosti $\bullet$ trg avtorskih pravic $\bullet$ search market

KONTAKTNI NASLOv: Dr. Jorg Sladič, docent, odvetniška pisarna Sladič - Zemljak, Kersnikova ul. 7, Sl-1000 Ljubljana, e-pošta: advokat.sladic@sedmica.net

ISSN 1855-7147 Tiskana izdaja / 1855-7155 Spletna izdaja C 2013 LeXonomica (Maribor) UDK: $347.78: 339.137$

JEL: K21, L40, O34

$\mathrm{Na}$ svetovnem spletu dostopno na http://www.lexonomica.com 


\section{Introduction}

In Slovenian law copyright or to be more exact the droitd'auteur (das Urbeberrecht, dirittod'autore) as Slovenia is a civil law nation is per definitioneman absolute right of private law appurtenant to intellectual property. Historically it is of territorial nature, though modern legal writers consider it to be of a ubiquitous nature (Schack, 2010: 432). In legal writing the difference between the droitd'auteur and copyright is defined by the difference of the approach to the person of the author. The droitd'auteur is intrinsically linked to the person of the author (Schack, 2010: 12). The Slovenian Act on Copyright and Neighboring Rights ${ }^{1}$ (Art. 14) therefore defines the copyright as belonging to the author by virtue of the creation of artistic work. The common law approach is a bit different and gives more emphasis to economic aspects (Art. 1 of British Copyright, Designs and Patents Act 1988 defines copyright as a property right which subsists in original literary, dramatic, musical or artistic works, sound recordings, films or broadcasts, and the typographical arrangement of published editions (Schack, 2010: 12). The structure of copyright can be presented using the following diagram developed by the Spanish Competition Authority (Commissiónnacional de la competencia, 2009: 15).

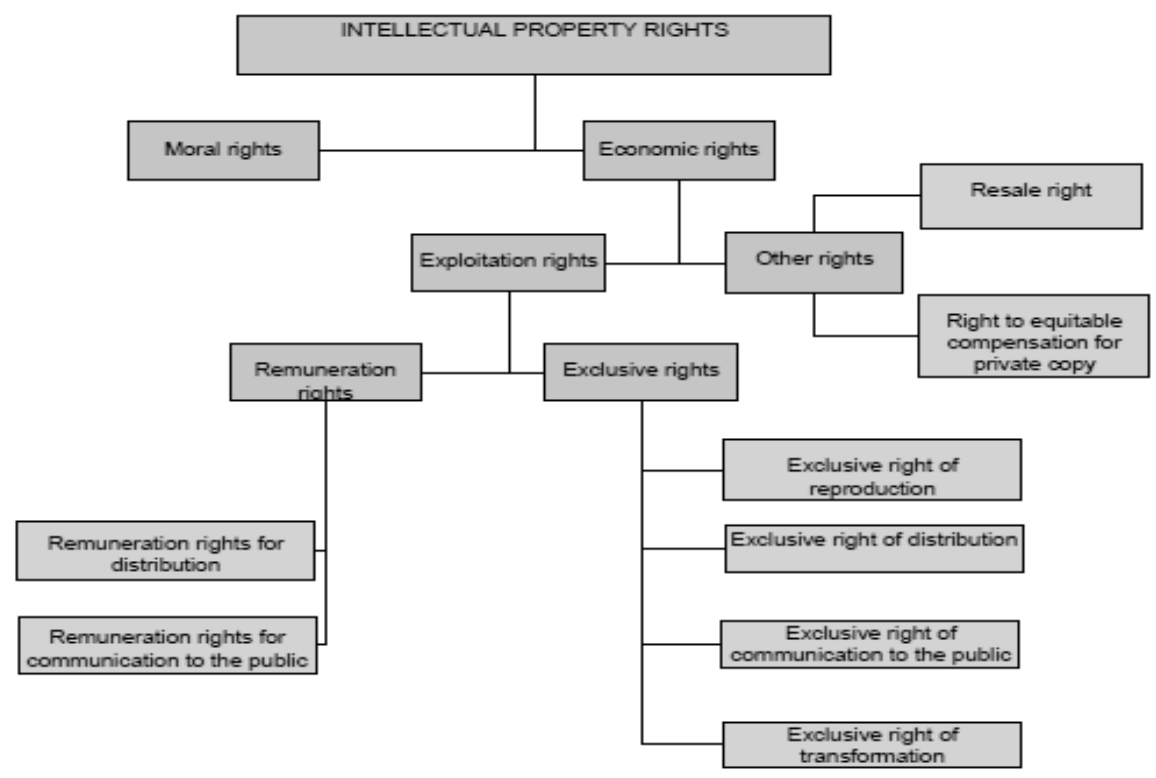

${ }^{1}$ Zakon o avtorski in sorodnih pravicah (hereinafter: ZASP), Official Journal of the Republic of Slovenia Nr. 21/1995, 9/2001, 17/2006, 139/2006 and 68/2008. 
However these conceptual differences do not seem to have any influence on the application of competition law. Copyright or the droit d'auteur produces as any other absolute right erga omnes effects. Next to the absolute effect, the copyright or the droit d'auteur also confers exclusive rights to the holder.

However, compared to classical property right on movable and immovable assets the phenomenon of Slovenian copyright is its division into two branches, namely the absolute moral right and the economic absolute rights. In principle Slovenian legal writing divides absolute rights as in other civil law legal systems into absolute individual personal rights (Persoenlichkeitsrechte) and absolute rights over objects (Herrschaftsrechte) (Berger, 2008: 22 and 23). Whereas as the moral right belongs to absolute individual personal rights, the economic part constitutes more or less absolute economic rights over objects. One can even claim that even in the field of the droit d'auteur "Intellectual property is like any other property, but not in all aspects" (Hewitt Pate, 2007: 3). Absolute economic rights over objects like property are usually administered individually. However, in Slovenia the solution is that the copyright or the droitd'auteurcan be administered collectively. The collective management is basically a form of assignment to a collecting society by authors in return for royalty payments (Fels, Walker, 2007: 333). "Collecting societies license out the use of copyrights in return for a fee that is collected and distributed back to the original owners less administrative costs" (Fels, Walker, 2007: 333). "The collecting societies acquire the management of copyright either by direct transfer from the authors or by transmission from another collecting society managing the same categories of rights in another country." 2 In some limited fields the collective management of copyright is mandatory (like in any other EU jurisdiction having implemented the Council Directive 93/83/EEC of 27 September 1993 on the coordination of certain rules concerning copyright and rights related to copyright applicable to satellite broadcasting and cable retransmission ${ }^{3}$ ).

This paper first gives a traditional ratio for collective management of copyright (Chapter 2), then the competition issues caused by a (at least a de facto) legal monopoly inherent to mandatory collective management (Chapters 3 and 4$)$.

\section{Rationale of collective management}

The central issue of a droit d'auteur or of a copyright is the remuneration and creation of a system encouraging the further development of an author's

\footnotetext{
${ }^{2}$ http:/ / curia.europa.eu/jcms/upload/docs/application/pdf/2013-04/cp130043en.pdf ${ }^{3}$ OJ L 248, 6. 10. 1993, p. 15.
} 
creativity and the creation of new protected works. A copyright or a droit $d^{\prime}$ auteur confers to its holder a legal monopoly comprising certain economic rights (like certain exclusive exploitation rights).

One of the questions is therefore how to achieve a workable system of remuneration for the use of artistic works. It has been stated that "in the area of copyright and neighbouring rights, the proper and fair participation of all concerned throughout the chain of exploitation and the rapid, fair and professional acquisition of rights are crucial for financial, as well as cultural, success" and that here is a "call that any use to be properly rewarded in accordance with the law applicable". "The sale of artistic works is somehow different to the sale of physical objects. The problems usually enumerated are the ubiquity of artistic works (just listen to the radio or TV) and the countless uses of works that are difficult to detect (like photocopying). The legally granted monopoly is of no use to the holder, it has no effet utile, if there is no practical way of enforcing it. The creation of collecting societies was the answer to such practical problems (Bertrand, 2011: 414). "Collecting societies acquire, administer and license copyrights and related rights, monitor their use, collect license fees and distribute them among their members" (Mestmäcker, 2007: 343). "Collecting societies are associations that enable authors to cooperate and sell jointly their rights under common commercial conditions" (Allendesalazar, Vallina, 2007: 371). Collecting societies are considered essentially as a natural monopoly (Fels, Walker, 2007: 334). The traditional economic rationale given in legal writing for statutory rules like collective management of copyright is supposed to be the reduction of (prohibitive) search and transaction costs that authors would incur in managing and administering their (small) rights (Jenny, 2007: 361 et seq). In other words, the issue is the economies of scale. ${ }^{5}$ The traditional legal rationale given by legal writing is that mandatory provisions on copyright management "aim at strengthening the position of authors" (von Lewinski, 2012: 112) vis-à-vis stronger and bigger users.

The market of copyright, especially in the field of music works, is a peculiar market that is described as a search market (Mestmäcker, 2007: 343 etseq). Compared to other market operators an author is in a very specific position as far as the exploitation and marketing are concerned. An author like a composer, a writer or even a painter does not need a physical infrastructure to create artistic works. Producers of goods and certain services sometimes need sophisticated infrastructure in order to produce goods or perform

\footnotetext{
${ }^{4}$ European Parliament resolution on a Community framework for collective management societies in the field of copyright and neighbouring rights of 15 January 2004 (2002/2274(INI), paras. 6 and 7 .

${ }^{5}$ Affaire COMP/C2/37.219 Banghalter\&Homem Christo v SACEM, Commission decision of 12 August 2002, p. 9.
} 
services. In order to produce a car one needs a car factory, in order to write a novel one only needs a pen and some sheets of paper (or a computer). Therefore the financial and liquidity risk of the supply side, usually seen on the market by the answer given by the demand side is different, the risk is never realised in a simultaneous manner as in an average market (Brekamp, 2003: 35). In other words, the market reaction to artistic works is usually delayed in time. In an average market the real value (the justum pretium) of goods and services is ensured by unrestricted competition (offer and demand). The distortion or restriction of competition is then remedied expost by competition law. The evaluation of the true price of an artistic or literary work does not follow the average market mechanisms. The creation of an author is unique; each artistic work differs from other artistic works, even if they are created by the same author. One cannot therefore speak of substitutability. To be a bit iconoclastic: bananas can be replaced by other fruits; a Picasso on the other hand can not be replaced by another picture. As far as artistic works are concerned, the demand does not reflect the real value of the work. Famous artists do benefit from their fame. Their name is so to speak a personal trade mark.

One additional characteristic of copyright is also that the author does not possess the same arsenal of legal remedies as e.g. a proprietor of moveable assets. A proprietor can always claim a reivindicatio and the restitution of his property. Once an artistic work is published (communicated to public) it can be used as often as the users require.

\section{Introductory issues of collective management in competition law}

\subsection{Introduction}

In this chapter I shall offer a brief overview of concepts like the principle of solidarity, the principle of territoriality and then mention the possibility of considering the collecting societies as services of general economic interest. Copyright does not preclude the application of competition law, and in that framework it does not preclude the application of provisions relating to the abuse of a dominant position.

The starting point is the Statement of the Court of Justice of the EU that "copyright-management societies pursue a legitimate aim when they endeavour to safeguard the rights and interests of their members vis-à-vis the users of recorded music. The contracts concluded with users for that purpose cannot be regarded as restrictive of 
competition for the purposes of Art. 101 [TFEU $\left.{ }^{6}\right]$ unless the contested practice exceeds the limits of what is necessary for the attainment of that aim."

\subsection{The principle of solidarity}

By reference to labour law and industrial relations it is argued by collecting societies that they adhere to the principles of organisation used by trade unions such as the principle of solidarity. Indeed, in competition law the principle of solidarity might preclude the application of competition law. ${ }^{8}$ Such a principle is the direct opposite of the competition by merits. However, such a principle can only be applied to the forum internum of the collecting society, i.e. in regulating legal relationships among authors within the collecting society but under the current state of the legislation it cannot $e x$ ante exclude the application of competition law for regulating the transactions between users and the authors as monopoly holders who are united or organised within a collecting society. Although copyright is not as such subject to the prohibitions contained in competition law, the exercise of such a right may, none the less, come within the said prohibitions where there are economic or legal circumstances the effect of which is to restrict distribution of artistic works to an appreciable degree or to distort competition on the relevant market, regard being had to the specific characteristics of that market. ${ }^{9}$ In other words, few collecting societies as unique and exclusively national organisations are in theory dealing with numerous users. It has to be stressed that collecting societies are a usual form of administration of copyright and neighbouring rights in the modern society. Legal writers have deduced from case law of the Court of Justice that their "market powver in relevant markets is usually a forgone conclusion" (Mestmäcker, 2007: 343). The problem from the point of view of competition law is a possible abuse of a dominant position.

Collecting societies are considered to have eo ipso a certain degree of market power and to behave like any other undertaking. However, it is also stated that there is certain conflict of interests within collecting societies, as the members of the collecting societies are often also the same persons or corporations who are the users of the artistic works, in other words the receivers of services provided by collecting societies are also the members of collecting societies (Jenny: 2007, 363-364).

\footnotetext{
${ }^{6}$ Treaty on the Functioning of the European Union (OJ C 326, 26.10.2012, p.47; Consolidated version).

${ }^{7}$ Case 395/87 Tournier ECR [1989] 2521, par. 31.

${ }^{8}$ Case C-350/07 KattnerStahlbau [2009] ECR I-1513, paras. 44-55.

${ }^{9}$ Case 262/81 Coditel I [1982] ECR 3381, par. 17.
} 


\subsection{Collective management as services of general economic interest}

Perhaps one should stress that the European Parliament adopted a resolution on a Community framework for collective management societies in the field of copyright and neighbouring rights (2002/2274(INI) ${ }^{10}$ which was then interpreted by legal writers as an attempt to convert collecting societies into a service of general economic interest within the meaning of Art. 106(2) TFEU and thus precluding at least a direct application of competition law to collecting societies (Mestmäcker, 2007: 344-345).

The Slovenian national legislation actually comes close to the exclusion of the application of competition law in some fields of collective management. Indeed, Art. 147 and Art. 151 ZASP provides for mandatory collective management ex lege without consent of the author of communication to the public of non-theatrical musical works and literary works (small rights), the resale of original works of fine art (resale right), the reproduction of works for private or other internal use and its photocopying and the cable retransmission of works, except in respect of broadcasters' own transmissions, irrespective of whether the rights concerned are their own or have been assigned to them by other right holders.

\subsection{The principle of territoriality and the collective management de jure condendo}

The alleged territoriality of copyright or of a droit d'auteur does not seem to have any bearing on the application of competition law. Indeed, modern copyright and the scope of its protection are defined by national legislation. ${ }^{11}$ However, as far as competition law is concerned it is deemed almost to be universal, therefore the classic issues of European competition law linked to the principle of territoriality of an intellectual property right are somehow of lesser importance. As far as territorial intellectual property rights are concerned, the proprietor of an industrial or commercial property right protected by the law of a Member State cannot rely on that law to prevent the importation of a product which has been lawfully marketed in another Member State by the proprietor himself or with his consent. ${ }^{12}$ Therefore the

\footnotetext{
10 European Parliament resolution of 15 January 2004 on a Community framework for collective management societies in the field of copyright and neighbouring rights (2002/2274(INI).

${ }^{11}$ Case T 420/08, SAZAS v. Commission, http://www.curia.europa.eu, par. 29.

12 Joined cases 55/80 and 57/80 GEMA [1981] ECR 147, par. 10.
} 
issue of territoriality is intrinsically directly linked to collecting societies, as they are due to regulatory requirements per definitionem national in scope. The principle of territoriality in copyright therefore reappears directly when dealing with collecting societies. As far as the definition of the geographical market is concerned, one has to refer to the Commission's decision in Daft Punk. ${ }^{13}$ Indeed, the geographical market is usually national according to the Commission.

The reaction to partitioning of the common single market is to be found in the Proposal for a Directive of the European parliament and of the Council on collective management of copyright and related rights and multi-territorial licensing of rights in musical works for online uses in the internal market. ${ }^{14}$ Collecting societies should be free to provide their services across borders to represent rightholders resident or established in other Member States or grant licences to users resident or established in other Member States.

\section{Relevant market and abuse of a dominant position}

\subsection{Introduction}

For the purposes of applying EU competition law the case law reiterates that in examining whether an undertaking holds a dominant position within the meaning of Art. 102 of the TFEU, it is of fundamental importance to define the market in question and to define the substantial part of the common market in which the undertaking may be able to engage in abuses which binder effective competition. The market for the product or service in question comprises all the products or services which in view of their characteristics are particularly suited to satisfy constant needs and are only to a limited extent interchangeable with other products or services. ${ }^{15}$ The General Court also explained that the definition of the relevant market differs according to whether Art. 101 TFEU or Art. 102 TFEU is to be applied. ${ }^{16}$

\footnotetext{
13 Affaire COMP/C2/37.219 Banghalter\&Homem Christo v SACEM, Commission decision of 12 August 2002, p. 8.

${ }^{14}$ COM/2012/0372 final - 2012/0180 (COD). The recital (3) reads: ,when established in the Union, collecting societies - as service providers - must comply with the national requirements pursuant to Directive 2006/123/EC of the European Parliament and of the Council of 12 December 2006 on services in the internal market1 which seeks to create a legal framework for ensuring the freedom of establishment and the free movement of services between the Member States. This implies that collecting societies should be free to provide their services across borders, to represent rightholders resident or established in other Member States or grant license to users resident or established in other Member States."

${ }^{15}$ Case C 7/97 Bronner [1998] ECR I 7791, paras. 32 and 33.

16 Joined cases T-259/02 to T-264/02 and T-271/02 RaiffeisenZentralbankÖsterreich and others v Commission [2006] ECR II-5169, par. 172.
} 


\subsection{Definition of the copyright related market}

Already from a legal point of view the definition of a relevant market in copyright is extremely complex. The European (single) market in copyright is still "totally compartmentalised" within frontiers of Member States and as Advocate General Jacobs states it is characterised by "a complete absence of competition, all of which would, in any other sector, be manifestly incompatible with Article 101(1) [TFEU]”.17

The conclusion of this reasoning is then drawn by Advocate General Kokott. According to her "a delimitation of the markets based on intellectual property rights means at best that access to the goods in question will be granted subject to differing conditions, in particular as regards prices or digital rights management. Often, however, access to such goods is completely precluded in many markets, either because certain language versions are offered only to customers from certain Member States or because customers from certain Member States cannot acquire the product at all." 18 However as far as copyright is concerned, the Advocate General Jacobs also explains that "the market is a wholly exceptional one, because of the unusual nature of the intellectual property rights in question, which are not only territorial in scope, regulated exclusively by national laws differing significantly among themselves, and incidentally subject to very long periods of protection, but which also require continuous supervision and management within the national territories if they are to be effectively exercised." 19

In the above mentioned attempts to define the market one might be surprised by the absence of the specific purpose of an intellectual property right. The specific purpose of intellectual property rights is to grant the holder the exclusive right to use that intellectual property right "and to probibit third parties from using it in the course of trade. In that way, the substantive law establishes a link between the protection of intellectual property rights and the existence of trade in the goods or services concerned' ${ }^{20}$ The teleological aim of copyright in EU legislation can for the time being be found in several acts of secondary legislation like the Directive 2006/115/EC of the European Parliament and of the Council of 12 December 2006 on rental right and lending right and on certain rights

17 Joined opinion of Advocate General Jacobs delivered on 26 May 1987 in joined cases 395/87 and 110/88, 241/88 and 242/88, Tournier and Lucazeau [1989] ECR 2521, par. 33.

18 Opinion of Advocate General Kokott delivered on 3 February 2011 in joined cases C403/08 and C-429/08, Football Association Premier League and others (C-403/08) and Karen Murphy (C-429/08), not yet reported in the ECR, par. 186.

19 Joined opinion of Advocate General Jacobs delivered on 26 May 1987 in joined cases 395/87 and 110/88, 241/88 and 242/88 Tournier and Lucazeau [1989] ECR p. 2521, par. 33.

${ }^{20}$ Opinion of Advocate General Cruz Villalón delivered on 3 February 2011 in joined cases C446/09 and C-495/09, Koninklijke Philips Electronics (C-446/09) and Nokia Corporation (C495/09), not yet published in the ECR, par. 49. 
related to copyright in the field of intellectual property (codified version) ${ }^{21}$ and Directive 2001/29/EC of the European Parliament and of the Council of 22 May 2001 on the harmonisation of certain aspects of copyright and related rights in the information society. ${ }^{22}$ As non distorted trade in goods and services is also the specific purpose ratione materiae of competition law (e.g. Art. 102 TFEU), it is therefore necessary to examine whether the specific subject-matter of a copyright requires a national partitioning of the internal market. ${ }^{23}$ Indeed, an abuse can consist in the fact that an undertaking entrusted with the exploitation of copyrights and occupying a dominant position imposes on its members obligations which are not absolutely necessary for the attainment of its object and which thus encroach unfairly upon a member's freedom to exercise his copyright. The inequitable nature of such provisions must be determined by the relevant court, bearing in mind both the intrinsic individual effect of those clauses and their effect when combined. ${ }^{24}$ However, a copyright management organisation with a dominant position on a substantial part of the common market does not abuse that position where, with respect to remuneration paid for the television broadcast of musical works protected by copyright, it applies to commercial television channels a remuneration model according to which the amount of the royalties corresponds partly to the revenue of those channels, provided that that part is proportionate overall to the quantity of musical works protected by copyright actually broadcast or likely to be broadcast, unless another method enables the use of those works and the audience to be identified more precisely without however resulting in a disproportionate increase in the costs incurred for the management of contracts and the supervision of the use of those works. ${ }^{25}$

As far as the definition of the relevant market is concerned, one has to refer to the Commission's decision in Daft Punk. ${ }^{26}$ The relevant product market is the rendering of services of management of artistic works of a certain category (the repertoire). The management consists in making the repertoire of music protected by copyright available to the users which have concluded licensing agreements with the collecting society. ${ }^{27}$ The next question is

\footnotetext{
21 OJ EU L 376, 27.12.2006, p. 28.

22 OJ EU L 167, 22.6.2001, p. 10.

23 Opinion of Advocate General Kokott delivered on 3 February 2011 in joined cases C403/08 and C-429/08, Football Association Premier League and Others (C-403/08) and Karen Murphy (C-429/08), not yet reported in the ECR, par. 179.

${ }^{24}$ Case 127/73 Belgische Radio en Televisie and Société belge des auteurs, compositeurs et éditeurs [1974] ECR, p. 313.

${ }^{25}$ Case C-52/07 Kanal 5 Ltd and TV 4 [2008] ECR I-9275, par. 41.

26 Affaire COMP/C2/37.219 Banghalter\&Homem Christo v SACEM, Commission decision of 12 August 2002, p. 8.

${ }^{27}$ Case C-52/07 Kanal 5 Ltd and TV 4 [2008] ECR I-9275, par. 29.
} 
whether the relevant market is determined by the whole repertoire, or just the segment of the repertoire of which the collecting society manages a certain category. ${ }^{28}$ The narrowest product market definition would distinguish between individual artists or even individual songs. However, retailers do not take such a limited approach..$^{29}$

Newer developments concerning the "national territorial limitations" are being observed as far as the application of new technologies is concerned in the context of the collective management in which the collecting societies operate..$^{30}$

\subsection{Abuse of a dominant position}

The majority of case law and legal writing examines the issue of an abuse of a dominant position in collective management. One of the most recent cases is that of Kanal 5 and TV 4 which concerns the abuse of a dominant position. A de facto monopoly of a collecting society suffices for a dominant position on the relevant market of protected works. ${ }^{31}$ As in other implementation of competition law the concept of abuse is an objective concept, which relates to the behaviour of an undertaking in a dominant position which influences the structure of a market where, as a result of the very presence of the undertaking in question, the degree of competition is weakened and which, through recourse to methods different from those that condition normal competition in products or services on the basis of the transactions of commercial operators, and has the effect of hindering the maintenance of the degree of competition still existing in the market or the growth of that competition. ${ }^{32}$ Legal writers make a distinction between the abuse of exploitation and the abuse of eviction. The abuse of exploitation is directed against the users and is usually exemplified by excessive pricing. However, the abuse of eviction is virtually impossible in case of mandatory collective management by operation of a law, as there are no competitors.

The usual complaint in collective management is the abusive or excessive pricing raised by users. If we consider the abuses linked to pricing, the analysis of case law shows that excessive pricing is considered abusive only in

\footnotetext{
${ }^{28}$ See to that effect French Conseil de la Concurrence, decision Nr. 05-D-16 of 26 April 2005, http://www.autoritedelaconcurrence.fr/user/avisdec.php?numero=05D16, par. 23.

${ }^{29}$ Commission Decision of 27 April, 1992 in Case No IV/M.202 - Thorn EMI/Virgin Music, par. 11.

${ }^{30}$ Case T 420/08, SAZAS v. Commission, http://www.curia.europa.eu, par. 76.

31 See per analogiam case C-52/07 Kanal 5 Ltd and TV 4 [2008] ECR, I-9275, paras. 19 and 20.

${ }^{32}$ Case C-52/07 Kanal 5 Ltd and TV 4 [2008] ECR I-9275, par 25.
} 
limited circumstances (Gstalter, 2012: 356). Discriminatory pricing on the other hand is inherent to copyright. The proprietor can act in a different manner if selling to a final consumer or to a distributor or even apply different conditions of sale to different countries. The discrimination is justified by the absolute and exclusive nature of a copyright (Gstalter, 2012: 358 and 359). However, in Europe such discrimination is limited by the doctrine of exhaustion, meaning plainly that parallel imports of copyright is allowed due to competition law concerns. ${ }^{33}$

As far as the abuse of a dominant position is concerned, the application of Art. 102 TFEU is rare due to the exploitation of copyright as an absolute and exclusive right. The explanation is not to be found in the preclusion of application of competition to copyright issues, but in the application of specific legal instruments offered by copyright like duty to conclude contracts imposed by mandatory national legislation (Art. 152 and 158 ZASP) (Gstalter, 2012: 499 and 500).

\section{Conclusion}

Collective management of copyright is a thorny issue in competition law. On one hand collective management is the best tool to reduce transaction costs and offers numerous advantages. On the other hand it can also be a source of abuse of a dominant position, as managing the copyright is considered an entrepreneurial activity and is thus covered by the scope of competition law. Bad application of competition law would directly undermine the absolute nature of a copyright. Therefore application of competition law to collective management of copyrights requires special attention.

\section{Literatura / References}

Allendesalazar, R., Vallina, R. (2007), Collecting Societies: The Usual suspects, in: Ehlermann, C. - D., Atanasiu, I. (eds.) (2007), European Competition Law Annual 2005, The Interaction between Competition Law and Intellectual Property Law, 371-398 (London: Hart Publishing).

Bernd, B. (2008), Allgemeines Schuldrecht (Bern: Staempfli).

Bertrand, A. R. (2011), Droit d'auteur 2011/2012 (Paris: Dalloz).

Brekamp, Ch. (2003), Einführung von Wettbewerbsstrukturen im Rahmen der kollektiven Verwertung, (Konstanz: University of Konstanz).

33 Albeit such a parallel import can de facto only be found in the field of multi-territorial licensing of online rights in "musical works". 
Commissiónnacional de la competencia (2009), Report on The Collective Management of Intellectual Property Rights, (Madrid: www.cncompetencia.es).

Fels, A., Walker, J. (2007), Australian Intellectual Property Law, Competition and Collecting Societies: Efficiency, Monopoly, Competition and Regulation, in: Ehlermann, C. - D., Atanasiu, I. (eds.) (2007), European Competition Law Annual 2005, The Interaction between Competition Law and Intellectual Property Law, 329-342 (London: Hart Publishing).

Gstalter, J. (2012), Droit de la concurrence et droits de propriété intellectuelle (Brussels: Bruylant).

Hewitt Pate, R. (2007), Pannel I: To What Extent Does IP Require/Justify A Special Treatment Under Competition Rules? in: Ehlermann, C. - D., Atanasiu, I. (eds.) (2007), European Competition Law Annual 2005, The Interaction between Competition Law and Intellectual Property Law, 3-33 (London: Hart Publishing).

Jenny, F. (2007), EC Competition Law Enforcement and Collecting Societies for Music Rights: What Are We Aiming For?, in: Ehlermann, C. - D., Atanasiu, I. (eds.) (2007), European Competition Law Annual 2005, The Interaction between Competition Law and Intellectual Property Law, 361-370 (London: Hart Publishing).

Lewinski von, S. (2012), Collectivism and its role in the frame of individual contracts, in: Rosén, J. (2012), Individualism and Collectiveness in Intellectual Property Law, 117-127 (Cheltenham, Edward Elgar Publishing).

Mestmäcker, E. - J. (2007), Collecting Societies, in: Ehlermann, C. - D., Atanasiu, I. (eds.) (2007), European Competition Law Annual 2005, The Interaction between Competition Law and Intellectual Property Law, 343-360 (London: Hart Publishing).

Schack, H. (2010) Urheber und Urhebervertragsrecht (Tübingen: J.C.B. Mohr). 